\title{
Influence of Extracellular Protein on the Cytoprotective Effects of Two Model Phytochemicals
}

\section{Maha J Hashim* and Jeffrey R Fry}

School of Life Sciences, University of Nottingham, Queen's Medical Centre, Nottingham, UK

\begin{abstract}
Consumption of antioxidant compounds in the diet may provide cytoprotection against oxidative damage associated with diseases or exposure to toxic agents. In the present study, we have investigated the influence of extracellular protein-binding on the cytoprotective properties of two free-radical-scavenging natural products: quercetin $(\mathrm{Q})$ and epigallocatechin-3-gallate (EGCG). Cytoprotection was determined by the ability of Q/EGCG to reduce the toxicity elicited by the oxidant tert-butyl hydroperoxide ( $t$-BHP) in human hepatoma HepG2 cells, performed in serum-free medium or medium containing low $[2 \%(v / v)]$ or high $[10 \%(v / v)]$ levels of foetal bovine serum. Initial studies confirmed that the presence of serum (up to $10 \% \mathrm{v} / \mathrm{v}$ ) was without effect on HepG2 viability. Furthermore, Q and EGCG were not toxic (up to a concentration of $100 \mu \mathrm{g} / \mathrm{mL}$ ) under any of the culture conditions. Cytoprotection elicited by $Q$ was significantly greater in serum-free and low-serum conditions compared to high-serum conditions. Similar results were obtained with EGCG, with additional evidence of a significant difference between serum-free and low-serum conditions. In conclusion, cytoprotective effects of $Q$ and EGCG are modified by the presence of extracellular protein
\end{abstract}

Keywords: Cytoprotection; Quercetin; Epigallocatechin-3-gallate; Protein-binding

\section{Introduction}

Cell metabolism constantly produces reactive oxygen species (ROS) as a natural by-product of the normal metabolism of oxygen [1]. This situation is not damaging because cells are able to compensate and maintain an adequate homeostasis between ROS production and its removal via enzymatic or non-enzymatic pathways [2-5]. On the other hand, if this balance is disturbed by an excessive accumulation of ROS [6] due to some reason related with environment, life style and pathologic factors these result in a situation called oxidative stress (OS). In consequence, this accumulation of ROS above the protection system of cells may damage the integrity and function of critical molecules, ultimately leading to cell death [3,7]. There is increasing evidence that oxidative stress contributes to disease conditions such as cancer, chronic obstructive pulmonary disease, asthma, cardiovascular dysfunction and immunosuppression $[8,9]$.

Quercetin (Q) (2-(3,4-dihydroxyphenyl)-3,5,7-trihydroxy-4H-1benzopyran-4-one; shown in Figure 1) is considered as one of the most abundant flavonoids and represents an integral part of human diet. High amounts of quercetin are found in numerous vegetables, fruits, nuts, tea, seeds and wine [10]. It exhibits a wide range of biological activities, including anti-inflammatory [11,12], anti-carcinogenic [13] and antiviral actions [14]. The chemoprevention elicited by polyphenols such as $\mathrm{Q}$ is mediated by apoptosis in tumor cells $[15,16]$ through direct activation of caspase cascade (mitochondrial pathway) such as caspase 3 and 9 as well as Bcl-2 family members $[17,18]$ but is without effect on their normal cell counterparts [19]. Moreover, it exerts a notable cytoptotection activity against t-BHP-induced oxidative stress in HepG2 cells [20].<smiles>O=c1c(O)c(-c2ccc(O)c(O)c2)oc2cc(O)cc(O)c12</smiles>

Figure 1: Structure of quercetin.<smiles>O=C(OC1Cc2c(O)cc(O)cc2OC1c1cc(O)c(O)c(O)c1)c1cc(O)c(O)c(O)c1</smiles>

Figure 2: Structure of epigallocatechin-3-gallate.

Epigallocatechin-3-gallate (EGCG; shown in Figure 2) is found in high amounts in green tea (Camellia sinesis), a popular drink throughout the world. EGCG is a potent chemopreventive agent, protecting against many types of cancer [21] such as those induced by chemicals or radiation [22,23], hepatic injury [24], as well as protecting cells from damage induced by free radicals [25]. The protective role of EGCG is selective, its effect being achieved in cancer cells but not in normal cells $[26,27]$. These differences in EGCG actions may be attributed to the differences between antioxidant defence mechanism in normal cells and mechanism of oxidative stress in cancer cells [21].

*Corresponding author: Maha J Hashim, Al-Gardens Street, Amman, Jordan E-mail: mahajalal_73@yahoo.com

Received December 04, 2018; Accepted December 11, 2018; Published December 25, 2018

Citation: Hashim MJ, Fry JR (2019) Influence of Extracellular Protein on the Cytoprotective Effects of Two Model Phytochemicals. Mol Biol 8: 227. doi: $10.4172 / 2168-9547.1000227$

Copyright: (c) 2019 Hashim MJ, et al. This is an open-access article distributed under the terms of the Creative Commons Attribution License, which permits unrestricted use, distribution, and reproduction in any medium, provided the origina author and source are credited. 
Q ad EGCG (and, indeed, many other naturally occurring polyphenolic antioxidants) are known to bind extensively to serum/ plasma proteins $[28,29]$, and a number of studies have demonstrated that the biological effects of chemicals to cells in culture is influenced by the presence of serum in the culture medium, this ascribed to the binding of the chemicals to the serum/plasma proteins [30-32]. Accordingly, in this study the influence of serum addition to culture medium on the antioxidant effects of Q and EGCG have been determined in an in vitro cytoprotection assay.

\section{Materials and Methods}

\section{Chemicals}

All chemicals used in this study were obtained from Sigma Chemical Co. Ltd., Poole, Dorset. UK, unless otherwise noted. Stock solutions of $\mathrm{Q}$ and EGCG were prepared in DMSO at $\mu \mathrm{g} / \mathrm{mL}$ concentration units and stored at $4^{\circ} \mathrm{C}$ until use. Q and EGCG were of $>95 \%$ purity, as specified by the supplier.

\section{Culture of HepG2 cells}

Human hepatoma HepG2 cells obtained from ECACC (Salisbury, UK), were cultured in $175 \mathrm{~cm}^{2}$ Nunclon culture flasks, in $5 \% \mathrm{CO}$ in air atmosphere at $37^{\circ} \mathrm{C}$ in humidified incubator prior to use, using $50 \mathrm{~mL}$ of minimum Essential Eagles MEM medium supplemented with 10\% (v/v) foetal calf serum, $2 \mu \mathrm{g} / \mathrm{mL}$ fungizone, $0.05 \mathrm{mg} / \mathrm{mL}$ gentamicin, $1 \%$ (v/v) non-essential amino acid solution, $2 \mathrm{mM} \mathrm{L}$-glutamine (standard culture medium). The cell stocks were sub-cultured by trypsinisation in a 1:8 split ratio at $80 \%$ confluence, once a week, with medium changes every 72 hrs. For experiments including treatments, cells were subcultured at high density in wells of a 24 -well plate in $1 \mathrm{~mL}$ standard culture medium; under these conditions confluence was achieved within $24 \mathrm{hrs}$.

\section{Cytoprotection assay}

The ability of plant-derived antioxidants to protect against the cytotoxicity elicited by the organic oxidant stressor t-BHP is a widely used model of cellular antioxidant activity $[3,20,30]$, and this model was used in the present study.

For this study, we chose liver as a model for toxicity due to its susceptibility to toxins and oxidative insults [33], and HepG2 cells were used to mimic non-dividing hepatic cells by culturing the cells in a highdensity confluent monolayer. Accordingly, HepG2 cells were seeded in wells of a 24-wells plate in $1 \mathrm{~mL}$ standard culture medium. After 24 hrs, cultures were exposed to different series of concentrations of $\mathrm{Q}$ or EGCG $(0-100 \mu \mathrm{g} / \mathrm{mL})$ with or without $0.8 \mathrm{mM}$ t-BHP simultaneously for $5 \mathrm{hrs}$ in serum-free medium or containing $2 \%(\mathrm{v} / \mathrm{v})$ or $10 \%(\mathrm{v} / \mathrm{v})$ serum, after which cell damage mediated by oxidant stress was assessed by neutral red uptake.

\section{Neutral red assay}

Cell viability determined by neutral red uptake is based on the incorporation and binding of neutral red into the lysosomes of viable cells [34]. The assay was performed as described by Adomaku-Bonsu et al. [35].

Evidence for changes in cell viability assessed by this assay were confirmed by repeated microscopic visualization of the cultures (data not shown).

\section{Statistical analysis}

Experimental data were entered into GraphPad Prism and analysed

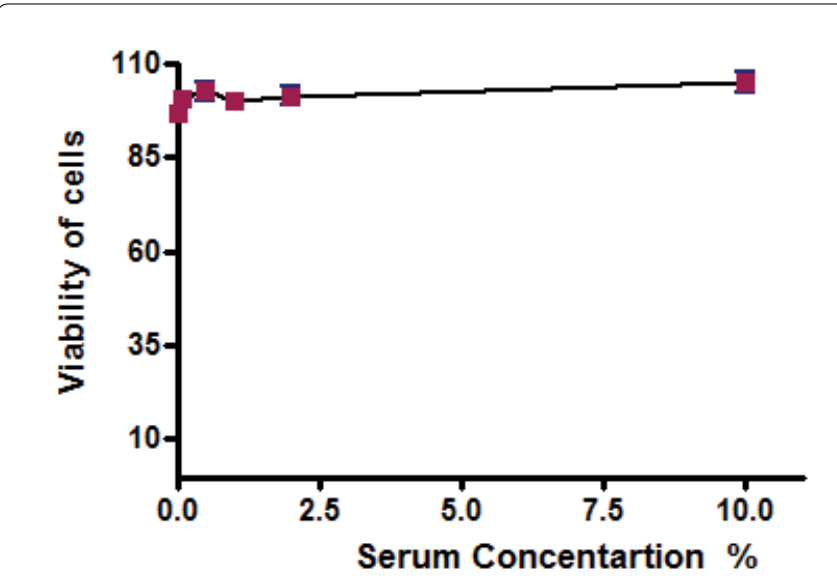

Figure 3: Effect of 5 hrs exposure to culture medium containing different serum concentrations on HepG2 cell viability. Values are mean \pm SEM of 3 independent experiments.

to identify the model that best fit the concentration-response curve, from which mean \pm S.D. EC values were determined for $Q$ and EGCG. Values were derived from at least 3 independent experiments. One-way ANOVA followed by selected comparisons by the Bonferroni method was used to compare the $\mathrm{EC}_{50}$ values obtained under different culture conditions.

\section{Results}

\section{Effect of serum}

Cell viability was not altered when cells were cultured for five hours in different serum conditions as shown in Figure 3. This allowed a further study of the cytoprotection provided by Q and EGCG, this time under standard (10\%) and reduced serum (2\%) and serum-free conditions.

\section{Cytoprotection activity of phytochemicals: Effect of serum}

Serum-free medium: When tested in serum-free medium, Q and EGCG were not toxic to the cells during incubation individually with HepG2 cells as shown in Figures 4a and b. When cells were incubated with Q and t-BHP simultaneously for $5 \mathrm{hrs,}$ Q protected against t-BHP toxicity in a concentration-dependent manner, cell viability reaching $80-100 \%$ at concentrations of $25-100 \mu \mathrm{g} / \mathrm{mL}$ and $\mathrm{EC}_{50}$ was $17.9 \pm 18$ $\mu \mathrm{g} / \mathrm{mL}$. Similarly, EGCG protected the cells against oxidative stress induced by $\mathrm{t}$-BHP in a concentration-dependent manner, and increased the viability of the cells to about $55-80 \%$ at concentrations of $25-100 \mu \mathrm{g} /$ $\mathrm{mL}$; $\mathrm{EC}_{50}$ was determined as $23.4 \pm 7.2 \mu \mathrm{g} / \mathrm{mL}$.

Medium 2\% serum: Results displayed no loss in cell viability when HepG2 cells were incubated with different concentrations of Q $(0-100 \mu \mathrm{g} / \mathrm{mL})$ in the presence of $2 \%$ serum. On the other hand when cells were exposed to t-BHP for $5 \mathrm{hrs}$ in the presence of $\mathrm{Q}$, cells were protected against toxicity by $\mathrm{Q}$ and protection was very notable as concentration of Q increased, to reach to about $90-95 \%$ at $100 \mu \mathrm{g} / \mathrm{mL}$ of $\mathrm{Q}$ and $\mathrm{EC}_{50}$ was recorded $16.1 \pm 2.4 \mu \mathrm{g} / \mathrm{mL}$ as shown in Figure $5 \mathrm{a}$. Under similar exposure conditions, viability of cells was maintained $100 \%$ during incubation with EGCG and EGCG was not toxic at any concentration used. An enhancement in protection was demonstrated when HepG2 cells were exposed to t-BHP in the presence of EGCG; cell viability gradually increased to $75 \%$ at $100 \mu \mathrm{g} / \mathrm{mL}$ EGCG and $\mathrm{EC}_{50}$ was $51.2 \pm 8.3 \mu \mathrm{g} / \mathrm{mL}$ as shown in Figure $5 \mathrm{~b}$. 

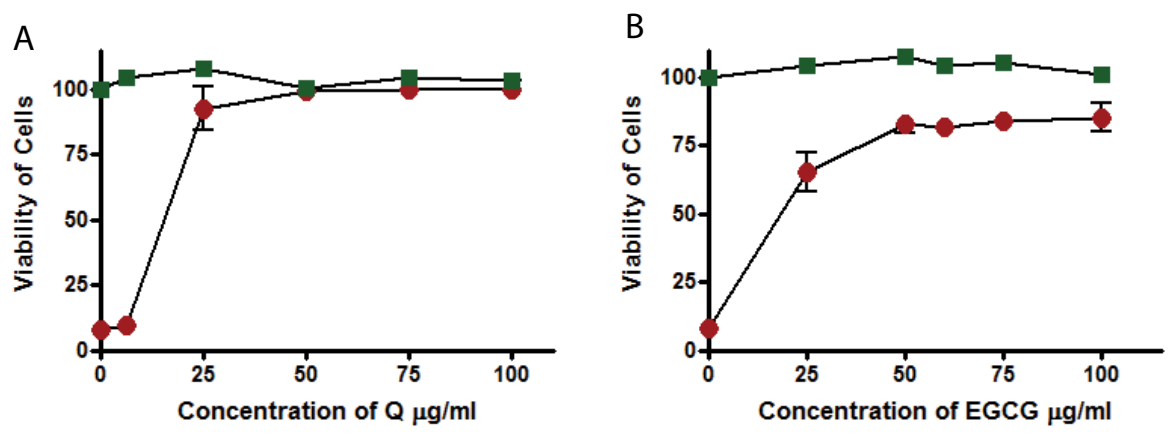

Figures 4a and b: Effect of 5 hrs exposure to (a) Q and (b) EGCG in serum-free medium on the viability of HepG2 cells, in the absence ( $\square$ ) or presence ( 0 ) of $0.8 \mathrm{mM}$ t-BHP. EC 50 values were $17.9 \pm 18$ and $23.4 \pm 7.2 \mu \mathrm{g} / \mathrm{mL}$ respectively. Values are mean \pm SEM of 3-7 independent experiments.
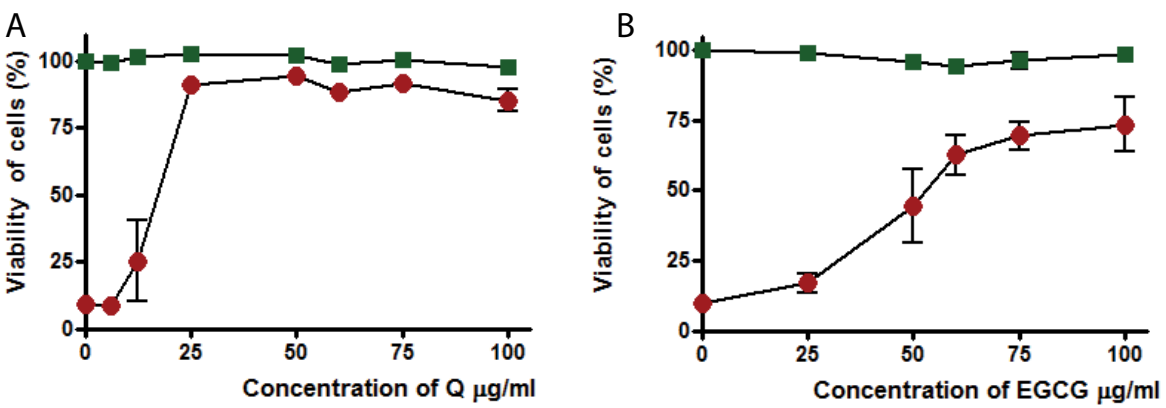

Figures 5a and b: Effect of 5 hrs exposure to (a) Q and (b) EGCG in medium containing $2 \%$ serum on the viability of HepG2 cells, in the absence ( $\square$ ) or presence ( ) of $0.8 \mathrm{mM}$ t-BHP. EC 50 values were $16.1 \pm 2.4$ and $51.2 \pm 8.3 \mu \mathrm{g} / \mathrm{mL}$ respectively. Values are mean \pm SEM of 3-7 independent experiments.
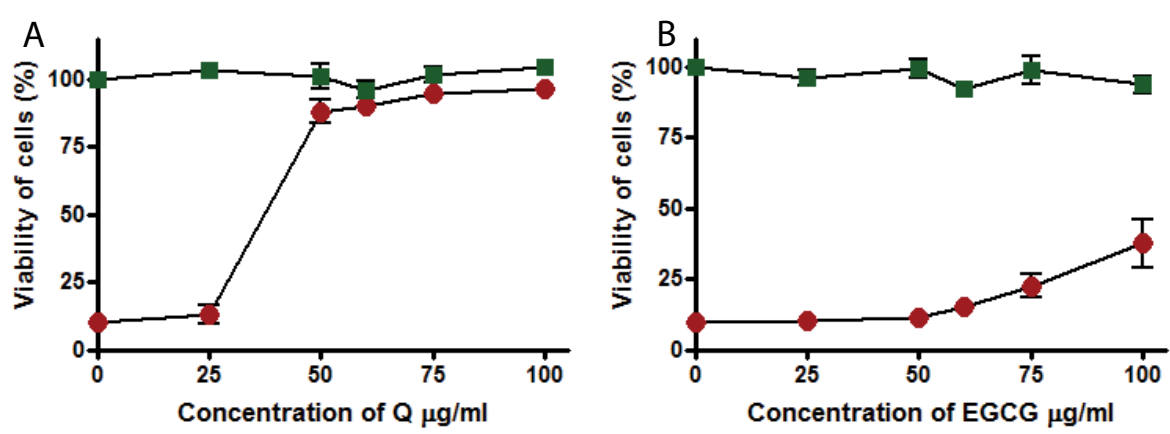

Figures $6 \mathbf{a}$ and $\mathbf{b}$. Effect of 5 hrs exposure to (a) Q and (b) EGCG in medium containing $10 \%$ serum on the viability of HepG2 cells, in the absence ( $\square$ ) or presence ( ) of $0.8 \mathrm{mM}$ t-BHP. EC $50(\mu \mathrm{g} / \mathrm{mL})$ for $Q$ and EGCG was $39 \pm 4.5$ and $84.7 \pm 7.4 \mu \mathrm{g} / \mathrm{mL}$ respectively. Values are mean \pm SEM of $3-7$ independent experiments.

Medium 10\% serum: When cells were cultured in medium containing $10 \%$ serum, cell viability was not affected by the incubation with Q for 5 hrs. Moreover, Q was able to protect HepG2 cells against oxidative stress induced by $\mathrm{t}-\mathrm{BHP}$ and cell viability reached to about 85 $90 \%$ at concentration of $100 \mu \mathrm{g} / \mathrm{mL}$ of $\mathrm{Q}$ and $\mathrm{EC}$ was $39 \pm 4.5 \mu \mathrm{g} / \mathrm{mL}$ as shown in Figure 6a. A notable positive relationship was reported for EGCG and cell viability for $5 \mathrm{hrs,} \mathrm{in} \mathrm{that} \mathrm{cytoprotection} \mathrm{was} \mathrm{increased} \mathrm{on}$ increase in the concentration of EGCG, and EC was $84.7 \pm 7.4 \mu \mathrm{g} / \mathrm{mL}$. Furthermore, EGCG was not toxic to HepG2 cell during the period of incubation as shown in Figure $6 \mathrm{~b}$. In addition, $\mathrm{Q}$ was significantly more active than EGCG (lower EC , $_{50} \mathrm{p} \leq 0.001$ ) (Table 1).

\section{Cytoprotection (expressed as $\mathrm{EC}_{50}$ in $\mu \mathrm{g} / \mathrm{mL}$ )}

Antioxidant Serum-free medium Medium $+2 \%$ serum Medium $+10 \%$ serum

\begin{tabular}{c|c|c|c|}
\hline $\mathbf{Q}$ & $17.9 \pm 1.8^{*}$ & $16.1 \pm 2.4^{*}$ & $39.9 \pm 4.5$ \\
\hline EGCG & $23.4 \pm 7.2^{* \circ}$ & $51.2 \pm 8.3^{*}$ & $84.7 \pm 7.4$ \\
\hline
\end{tabular}

Note: $\mathrm{EC}_{50}=$ the effective concentration of phytochemical providing $50 \%$ protection Values are reported as mean \pm S.D of 3-7 separate experiments. Data analysis was carried out as described in 'Materials and Methods'. Where indicated by

*, values are significantly different $(P<0.001)$ to that for medium $+10 \%$ serum. Where indicated by ${ }^{\circ}$, value is significantly different to that in medium $+2 \%$ serum $(P<0.001)$.

Table 1: Influence of medium conditions on the cytoprotection exerted by $Q$ and EGCG against oxidative stress toxicity elicited by t-BHP. 


\section{Discussion}

The data presented in this report demonstrate that the presence of serum, and by implication, its protein component, modifies the cytoprotection action of Q and EGCG in human hepatoma HepG2 cells exposed to an oxidative stress elicited by t-BHP. This is most clearly demonstrated in the data in Table 1, which is a summary of the individual data presented in Figures 4-6. These data add to the body of literature illustrating the role of serum in the biological actions of organic compounds on cells in culture (see Introduction), and this report is one of the few that specifically does so in the context of cytoprotection against oxidative stress, is are consistent with previous reports on the role of protein binding on antioxidant behavior of phenolic compounds in a non-cellular environment [36-38].

The modulatory effect of serum on biological actions in cell culture models is ascribed to the binding of organic compounds to proteins, predominantly albumin, present in serum, so reducing the "free" biologically active fraction in the culture medium. This interpretation is consistent with the extensive binding of Q, EGCG and related compounds that has been reported by others (see Introduction).

An important determinant in the binding affinity of Q, EGCG and related compounds to albumin appears to be the presence of multiple free hydroxyl groups in their structure (Figures 1 and 2) $[29,39,40]$. The effectiveness of Q, EGCG and related compounds as antioxidants and, hence, cytoprotectants, is similarly strongly dependent on the presence of multiple free hydroxyl groups [41-43]. This consideration is in keeping with the study reported by Wang and Goodman [38], who demonstrated a significant positive correlation of protein binding of dietary phenols with their antioxidant properties. Consequently, attempts at chemical modification of the structure of Q, EGCG and related compounds to minimize their protein binding affinity is likely to also reduce their antioxidant and cytoprotection properties.

Having established that the presence of serum in culture medium reduces the cytoprotection effectiveness of Q and EGCG, the question arises as to which cell culture conditions might most mimic the in vivo situation. The answer to this is not straightforward.

The albumin content of foetal bovine serum, the serum used in this study, is in the range $15-25 \mathrm{~g} / \mathrm{L}[30,44]$, so the albumin content of media containing $2 \%$ and $10 \%$ foetal bovine serum would be in the order of 0.4 and $2 \mathrm{~g} / \mathrm{L}$ respectively. Whilst there are appreciable technical difficulties in the sampling of interstitial fluid (ISF), it is generally accepted that the albumin content of ISF is of the order of $15-18 \mathrm{~g} / \mathrm{L}[45,46]$, although a more recent study suggests a tissue level of approximately 1-2 g/L [47]. However, in human cerebrospinal fluid (CSF) the albumin content is less than $0.3 \mathrm{~g} / \mathrm{L}[48,49]$. In light of these observations then, cytoprotection assays performed in medium containing the higher levels of serum may reflect the in vivo situation in ISF, whereas assays performed in medium containing low levels of serum or in serum-free medium may reflect the in vivo situation in CSF

\section{Conclusion}

In the present study we have demonstrated that the presence of serum in the culture medium modifies the cytoprotective effects of Q and EGCG, an effect which we ascribe to the well-characterized protein-binding effects of both compounds. Comparison of the protein concentrations in the various culture models used in this study with those measured in various body fluid compartments points to both low-serum and high-serum cell culture models being of relevance to prediction of likely in vivo antioxidant behavior of these naturally occurring polyphenolic compounds.

\section{Acknowledgment}

Maha Hashim would like to acknowledge The University of Nottingham and School of Life Sciences (U.K.) for all scientific support. More thanks to my supervisor in $\mathrm{PhD}$ (including this research), Dr. Jeffrey R Fry, for all his guidance, assistance and patience.

All words in the world are not enough to thank my dad (Jalal Hashim Mohammed Tabana), in Iraq, who has funded my PhD study (including this research) with all living cost in the United Kingdom for five years.

\section{References}

1. Wagner C, Fachinetto R, Dalla Corte CL, Brito VB, Severo D, et al. (2006) Quercitrin, a glycoside form of quercetin, prevents lipid peroxidation in vitro. Brain Res 1107(1): 192-8.

2. Lawless MW, O'Byrne KJ, Gray SG (2009) Oxidative stress induced lung cancer and COPD: Opportunities for epigenetic therapy. J Cell Mol Med 13(9a): 2800-2821.

3. Lima CF, Valentao PC, Andrade PB, Seabra RM, Fernandes-Ferreira M, et al (2007) Water and methanolic extracts of Salvia officinalis protect HepG2 cells from t-BHP induced oxidative damage. Chem-Biol Interact 167(2): 107-115.

4. Mittal A, Pathania V, Agrawala PK, Prasad J, Singh S, et al. (2001) Influence of Podophyllum hexandrum on endogenous antioxidant defence system in mice: possible role in radioprotection. J Ethnopharmacol 76(3): 253-262.

5. Palmieri B, Sblendorio V (2006) Oxidative stress detection: what for? Part I Eur Rev Med Pharmacol Sci 10(6): 291-317.

6. Jeong YM, Choi YG, Kim DS, Park SH, Yoon JA, et al. (2005) Cytoprotective effect of green tea extract and quercetin against hydrogen peroxide-induced oxidative stress. Arch Pharmacal Res 28(11): 1251-1256.

7. Kim JA, Kang YS, Kim YO, Lee SH, Lee YS (1998) Role of Ca2+ influx in the tert- butyl hydroperoxide-induced apoptosis of HepG2 human hepatoblastoma cells. Exp Mol Med 30: 137-144.

8. Lopaczynski W, Zeisel SH (2001) Antioxidants, programmed cell death, and cancer. Nutr Res 21: 295-307.

9. Riboli E, Norat T (2003) Epidemiologic evidence of the protective effect of fruit and vegetables on cancer risk. Am J Clin Nutr 78: 559s- 569s.

10. Lesser S, Wolffram S (2006) Oral bioavailability of the flavanol quercetin-A review. Curr Top Nutraceutical Res 4(3-4): 239-256.

11. Loke WM, Proudfoot JM, Stewart S, Mckinley AJ, Needs PW, et al. (2008) Metabolic transformation has a profound effect on anti-inflammatory activity of flavonoids such as quercetin: Lack of association between antioxidant and lipoxygenase inhibitory activity. Biochem Pharmacol 75(5): 1045-1053.

12. Shimoda K, Kobayashi T, Akagi M, Hamada H, Hamada H (2008) Synthesis of oligosaccharides of genistein and quercetin as potential anti-inflammatory agents. Chem Lett 37(8): 876-877.

13. Jagtap S, Meganathan K, Wagh V, Winkler J, Hescheler J, et al. (2009) Chemopreventive mechanism of the natural compounds, epigallocatechin-3O-gallate, quercetin and curcumin against cancer on cardiovascular diseases. Curr Med Chem 16(12): 1451-1462.

14. Fan DS, Zhou X, Zhao C, Chen HG, Zhao Y, et al. (2011) Anti-inflammatory antiviral and quantitative study of quercetin-3-O-beta-D-glucuronide in Polygonum perfoliatum L. Fitoterapia 82(6): 805-810.

15. Kaufmann SH, Earnshaw WC (2000) Induction of apoptosis by cancer chemotherapy. Exp Cell Res 256(1): 42-49.

16. Ramos S (2007) Effects of dietary flavonoids on apoptotic pathways related to cancer chemoprevention. J Nutr Biochemi 18(7): 427-442.

17. Granado-Serrano AB, Angeles MM, Bravo L, Goya L, Ramos S (2008) Timecourse regulation of quercetin on cell survival/proliferation pathways in human hepatoma cells. Mol Nutr Food Res 52(4): 457-464.

18. Granado-Serrano AB, Martin MA, Bravo L, Goya L, Ramos S (2006) Quercetin induces apoptosis via caspase activation, regulation of $\mathrm{Bcl}-2$, and inhibition of $\mathrm{PI}-3-k i n a s e / A k t$ and ERK pathways in a human hepatoma cell line (HepG2). J Nutr 136(11): 2715-21.

19. Chowdhury SA, Kishino K, Satoh R, Hashimoto K, Kikuchi H, et al. (2005) Tumor-specificity and apoptosis- inducing activity of stilbenes and flavonoids. Anticancer Res 25(3B): 2055-2063. 
Citation: Hashim MJ, Fry JR (2019) Influence of Extracellular Protein on the Cytoprotective Effects of Two Model Phytochemicals. Mol Biol 8: 227. doi: $10.4172 / 2168-9547.1000227$

Page 5 of 5

20. Abu Bakar MF, Mohamed M, Rahmat A, Burr SA, Fry JR (2013). Cellular assessment of the extract of bambangan (Mangifera pajang) as a potential cytoprotective agent for the human hepatocellular HepG2 cell line. Food Chem 136(1): 18-25.

21. Raza H, John A (2005) Green tea polyphenol epigallocatechin-3-gallate differentially modulates oxidative stress in PC12 cell compartments. Toxicol Appl Pharmacol 207(3): 212-220.

22. Dreosti IE, Wargovich MJ, Yang CS (1997) Inhibition of carcinogenesis by tea: The evidence from experimental studies. Crit Rev Food Sci Nutr 37(8): 761-770.

23. Gensler HL, Timmermann BN, Valcic S, Wächter GA, Dorr R, et al. (1996) Prevention of photocarcinogenesis by topical administration of pure epigallocatechin gallate isolated from green tea. Nutr Cancer 26(3): 325-335.

24. Zhong Z, Froh M, Connor HD, Li X, Conzelmann LO, et al. (2002) Prevention of hepatic ischemia-reperfusion injury by green tea extract. Am J Physio Gastrointest Liver Physiol 283(4): G957-G964.

25. Guo QN, Zhao BL, Li MF, Shen SR, Xin WJ (1996) Studies on protective mechanisms of four components of green tea polyphenols against lipid peroxidation in synaptosomes. Biochim Biophys Acta 1304 (3): 210-222.

26. Chung JH, Han JH, Hwang EJ, Seo JY, Cho KH, et al. (2003) Dual mechanisms of green tea extract- induced cell survival in human epidermal keratinocytes. FASEB J 17(13): 1913-1915.

27. Gupta S, Hastak K, Afaq F, Ahmad N, Mukhtar H (2004) Essential role of caspases in epigallocatechin-3-gallate-mediated inhibition of nuclear factor kappa B and induction of apoptosis. Oncogene 23(14): 2507-2522.

28. Bolli A, Marino M, Rimbach G, Fanali G, Fasano M, et al. (2010) Flavonoid binding to human serum albumin. Biochem Biophys Res Commun 398(3): 444-449.

29. Trnkova L, Bousova I, Stankova V, Drsata J (2011) Study on the interaction of catechins with human serum albumin using spectroscopic and electrophoretic techniques. J Mol Struct 985(2-3): 243-250.

30. Gulden M, Dierickx P, Seibert H (2006) Validation of a prediction model for estimating serum concentrations of chemicals which are equivalent to toxic concentrations in vitro. Toxicol in Vitro 20(7): 1114-1124.

31. Kanno S, Kurauchi K, Tomizawa A, Yomogida S, Ishikawa M (2011) Albumin modulates docosahexanoic acid-induced cytotoxicity in human hepatocellular carcinoma cell lines. Toxicol Letters 200(3): 154-161.

32. Kramer NI, Krismartina M, Rico-Rico A, Blauuboer BJ, Hermens JLM (2012) Quantifying processes determining the free concentration of phenanthrene in basal cytotoxicity assays. Chem Res Toxicol 25(2): 436-445.

33. Martin MA, Ramos S, Mateos R, Granado Serrano AB, Izquierdo-Pulido M, et al. (2008) Protection of human HepG2 cells against oxidative stress by cocoa phenolic extract. J Agric Food Chem 56(17): 7765-72.

34. Repetto G, del Peso A, Zurita JL (2008) Neutral red uptake assay for the estimation of cell viability/cytotoxicity. Nat Protoc 3(7): 1125-1131.
35. Adomako-bonsu AG, Chan SLF, Pratten M, Fry JR (2017) Antioxidant activity of rosmarinic acid and its principal metabolites in chemical and cellular systems: Importance of physico-chemical characteristics. Toxicol in Vitro 40: 248-225.

36. Arts MJTJ, Haenen GRMM, Wilms LC, Beetstra SAJN, Heijnen CGM, et al. (2002) Interactions between flavonoids and proteins: effect on the total antioxidant capacity. J Agric Food Chem 50(5): 1184-1187.

37. Rohn S, Rawel HM, Kroll J (2004) Antioxidant activity of protein-bound quercetin. J Agric Food Chem 52(15): 4725-4729.

38. Wang W, Goodman MT (1999) Antioxidant property of dietary phenolic agents in a human LDL-oxidation ex vivo model; interaction of protein binding activity. J Food Nutr Res 19(2): 191-202.

39. D’Archivio M, Filesi C, Di Benedetto R, Gargiulo R, Giovannini C, et al. (2007) Polyphenols, dietary sources and bioavailability. Ann Ist Super Sanita 43(4): 348-61.

40. Xiao JB, Kai GY (2012) A review of dietary polyphenol-plasma protein interactions: Characterization, influence on the bioactivity, and structure-affinity relationship. Crit Rev Food Sci Nutr 52(1): 85-101.

41. Ben SM, Skandrani I, Nasr N, Franca MG, Chekir-Ghedira L, et al. (2011) Flavonoids and sesquiterpenes from Tecurium ramosissimum promote antiproliferation of human cancer cells and enhance antioxidant activity: A structure-activity relationship study. Environ Toxicol Pharmacol 32: 336-348.

42. Heim KE, Tagliaferro AR, Bobilya DJ (2002) Flavonoid antioxidants: Chemistry metabolism and structure-activity relationships. J Nutr Biochem 13: 572-584.

43. Lien EJ, Ren S, Bui HH, Wang R (1999) Quantitative structure-activity relationship analysis of phenolic antioxidants. Free Radic Biol Med 26: 285294.

44. ELISA kit data (2018). Retrieved from https://www.4adi.com/objects/catalog/ product/extras/16672 8100-BSA-ELISA-Manual.pdf on 26 November 2018.

45. Wiig H, Reed RK, Tenstad O (2000) Interstitial fluid pressure, composition of interstitium, and interstitial exclusion of albumin in hypothyroid rats. Am J Physiol Heart Circ Physiol 278: 1627-1639.

46. Vincent JL, Russell JA, Jacob M, Martin G, Guidet B et al (2014). Albumin administration in the acutely ill: what is new and where next? Critical Care 18: 231-241.

47. Richardson OC, Bane O, Scott MLJ, Tanner SF, Waterton JC, et al. (2015) Gadofosveset-based biomarker of tissue albumin concentration: technical validation in vitro and feasibility in vivo. Magn Reson Med 73: 244-253.

48. Wang R, Guan HZ, Ren HT, Wang W, Hong Z, et al. (2015) CSF findings in patients with anti-N-methyl-D-aspartate receptor-encephalitis. Seizure 29: $137-$ 142

49. Reiber H (2016) Knowledge-base for interpretation of cerebrospinal fluid data patterns. Essentials in neurology and psychiatry. Arquivos de Neuro-psiquiatria 74: $501-512$ 